\title{
Pendekatan Matematika Realistik dengan Bantuan Puzzle Pecahan untuk Siswa Sekolah Dasar
}

\author{
Achmad Firdaus \\ ah.fird79@gmail.com \\ SD Al Muslim, Yayasan Al Muslim Bekasi

\begin{abstract}
REALISTIC MATHEMATICAL APPROACH WITH THE HELP OF FRACTION PUZZLE FOR
\end{abstract} \\ PRIMARY GRADES STUDENTS
}

\begin{abstract}
There are still many students who have difficulties in learning fractions, because instructional is often delivered with abstract which is dominated by formal methods. Therefore, a new approach is needed, accompanied by adequate learning media to overcome the problems mentioned above. A realistic mathematical approach with the help of fractional puzzles was designed to help students to explain the abstract situations of a problem into a realistic form then developed to direct students to mathematically search solutions. The place of this study was in SD al Muslim Tambun with the research subjects of the fourth grade students of Ibnu Rusyd 2015/2016 Academic Year as many as 28 students. This is a Class Action Research with 2 trial cycles. The data was analyzed by comparing conventional techniques without learning media with realistic mathematical approaches with the help of fractional puzzles. The results shows that in the first cycle experiment there was an increase in the average value of learning outcomes of $15.64 \%$ with an average grade of 75.4. Then in the second cycle experiment there was an increase in the average value of student learning outcomes by $23.31 \%$ with an average grade value of 80.4 . It can be concluded that the realistic mathematical approach with the help of fractional puzzles can increase the value of student learning outcomes in fraction addition material with the same denominator in elementary school.
\end{abstract}

Keywords: realistic mathematics approach, fractional puzzle learning media, primary school

Received date: 4 Mei 2018

Article Info

Revised date: 19 Juli 2018

Accepted date: 21 September 2018

\section{PENDAHULUAN}

Pada dasarnya matematika senantiasa ada pada semua kurikulum sekolah. Mulai dari kurikulum sekolah tingkat Taman Kanak-Kanak sampai kurikulum sekolah tingkat Perguruan Tinggi, matematika senantiasa termasuk salah satu materi yang tercakup dalam kurikulum.

Matematika berfungsi mengembangkan kemampuan menghitung, mengukur, menurunkan dan menggunakan rumus matematika yang diperlukan dalam kehidupan sehari-hari melalui materi aljabar, geometri, logika matematika, peluang dan statistika. Matematika juga berfungsi mengembangkan kemampuan mengkomunikasikan gagasan melalui model matematika yang dapat berupa kalimat dan persamaan matematika, diagram, grafik atau tabel (Depdiknas, 2003:6).

Begitu penting peranan matematika dalam kehidupan sehari-hari sehingga para peserta didik diharapkan dapat menguasai dari setiap tujuan pembelajaran matematika. Agar tersampaikan dengan baik tujuan pembelajaran matematika diharapkan pendekatan dan strategi pembelajaran hendaknya mengikuti kaidah pedagogik secara umum, yaitu pembelajaran diawali dari kongkrit ke abstrak, dari sederhana ke kompleks, dan dari mudah ke sulit, dengan menggunakan berbagai sumber belajar (Depdiknas, 2003:11).

Pemahaman konsep dalam belajar matematika mutlak dikuasai oleh siswa sebagai dasar untuk menguasai matematika itu sendiri serta menunjang perkembangan cabang-cabang ilmu lainnya. Bidang studi matematika yang diajarkan pada siswa SD mencakup tiga cabang, yaitu bilangan, 
geometri an pengukuran, serta pengolahan data (Kisi-kisi USBN SD/MI 2018). Dari ketiga cabang itu, bilangan khususnya pokok bahasan pecahan adalah salah satu cabang yang dirasa sulit karena memerlukan penguasaan konsep yang lebih mendalam. Sebagai dasar dan ilmu penunjang sehingga sudah sepatutnya pelajaran matematika disampaikan dengan baik dan benar apalagi kalau sudah berbicara konsep dasar.

Pokok bahasan pecahan mulai diperkenalkan pada siswa SD kelas 3, dengan materi pengenalan pecahan, membandingkan pecahan, dan operasi hitung penjumlahan dan pengurangan pecahan berpenyebut sama. Sehingga pada kelas berikutnya yaitu kelas 4, 5 dan 6 materi pecahan ini mengalami pendalaman materi. Jika masalah pemahaman konsep tentang pecahan ini, terutama pada operasi hitung pecahan, tidak kita cari solusi sejak dini. Sudah dapat dipastikan bahwa selamanya peserta didik kita mengalami miskonsepsi tentang pecahan.

Pengalaman belajar dengan benda-benda kongkrit yang dimiliki dan dikenal anak sebagai peserta didik sangat membantu dalam mendasari pemahaman konsep-konsep yang abstrak. Guru harus terampil membangun jembatan penghubung antara pengalaman kongkrit dengan konsep-konsep matematika yang abstrak. Oleh karena itu benda-benda nyata dan benda-benda yang dimanipulasi akan sangat membantu anak pada tingkat sekolah dasar dalam belajar matematika. Dengan demikian, penggunaan media pembelajaran terutama benda nyata dan alat peraga memiliki peranan yang penting dalam kegiatan pembelajaran matematika di SD untuk mencapai pemahaman dan pemaknaan matematika.

Namun pada kenyataannya seringkali para pendidik menyampaikan materi pecahan kepada siswa menggunakan cara yang konvensional, tidak menggunakan media pembelajaran. Akibatnya banyak para siswa yang tidak memahami konsep pecahan secara baik dan benar. Para pendidik di sekolah khususnya di SD al muslim belum menemukan media belajar untuk mengatasi masalah tersebut, sehingga seringkali siswa mendapatkan nilai hasil belajar yang kurang memuaskan pada materi pecahan. Jika hal ini dibiarkan terus menerus akan menimbulkan kejenuhan pada siswa dalam mempelajari pecahan yang pada akhirnya para siswa akan benci matematika. Untuk itulah puzzle pecahan hadir sebagai solusi mengatasi permasalahan di atas. Puzzle pecahan sangat mudah dibuat oleh guru dengan biaya yang relatif terjangkau, penggunaannya pun sangat mudah untuk guru maupun siswa.

Berdasarkan pengalaman peneliti mengajarkan materi pecahan dengan cara konvensional ditemukan permasalahan bahwa pencapaian nilai rata-rata kelas terhadap materi penjumlahan pecahan berpenyebut tidak sama hanya sebesar 65,2 dan sebanyak $60,71 \%$ nilai hasil belajar siswa berada di bawah KKM. Secara umum penelitian ini bertujuan untuk meningkatkan pemahaman konsep tentang pecahan pada siswa dan penyelesaian operasi hitung pecahan serta melihat aktivitas belajar siswa yang menyenangkan tentang operasi hitung hitung pada pecahan menggunakan puzzle pecahan. Sedangkan secara khusus penelitian ini bertujuan untuk meningkatkan nilai hasil belajar siswa khususnya di SD al muslim pada materi pecahan. Juga melihat efektifitas penggunaan puzzle pecahan terhadap peningkatan hasil belajar siswa dalam mempelajari materi pecahan khususnya di kelas 4 SD al muslim.

\section{KAJIAN PUSTAKA}

Azhar (2011:8) media pembelajaran adalah alat bantu pada proses belajar baik didalam maupun diluar kelas, lebih lanjut dijelaskan bahwa media pembelajaran adalah komponen sumber belajar atau wahana fisik yang mengandung materi instruksional dilingkungan siswa yang dapat merangsang siswa untuk belajar. Sedangkan Maria dan Wahyudi (2016:145) menyatakan bahwa media pembelajaran adalah media yang digunakan untuk mendukung proses pembelajaran di kelas dan membantu menumbuhkan motivasi belajar siswa.

Menurut Arief Sadiman (2008:7) bahwa media belajar adalah segala sesuatu yang dapat digunakan untuk menyalurkan pesan dari pengirim ke penerima pesan. Sedangkan Rayanda Asyar (2012:8) mengemukakan bahwa media pembelajaran dapat dipahami sebagai segala sesuatu yang dapat menyampaikan atau menyalurkan pesan dari sumber secara terencana, sehingga terjadi lingkungan belajar yang kondusif dimana penerimanya dapat melakukan proses belajar secara efisien dan efektif. Selanjutnya Syaful Bahri Djamarah dan Azwan Zain (2010:121) mengungkapkan bahwa 
media pembelajaran adalah alat bantu apa saja yang dapat dijadikan sebagai penyalur pesan agar tercapai tujuan pembelajaran.

Dari uraian-uraian di atas jelaslah bahwa pengertian media belajar adalah segala sesuatu alat bantu yang dapat digunakan untuk menyalurkan pesan dari seorang pendidik kepada para siswanya yang diharapkan dapat mendorong terjadinya proses belajar pada diri siswa untuk mencapai tujuan pembelajaran.

Menurut beberapa sumber ahli tersebut di atas, lebih lanjut mengatakan bahwa tujuan dan manfaat media belajar adalah sebagai berikut : (1) Media belajar bertujuan agar proses pendidikan lebih efektif dengan jalan meningkatkan semangat belajar siswa. (2) media belajar memungkinkan lebih sesuai dengan perorangan, dimana para siswa belajar dengan banyak kemungkinan sehingga belajar berlangsung sangat menyenangkan bagi masing-masing individu. (3) Media belajar memiliki manfaat agar belajar lebih cepat segera bersesuaian antara kelas dan diluar kelas, alat perga juga memungkinkan mengajar lebih sistematis dan teratur.

Secara ringkas, proses pembelajaran memerlukan media yang penggunaannya diintegrasikan dengan tujuan dan isi atau materi pelajaran yang dimaksudkan untuk mengoptimalkan pencapaian suatu tujuan pengajaran yang telah ditetapkan. Fungsi media belajar dimaksudkan agar terjadi komunikasi antara guru dan siswa dalam hal penyampaian pesan, siswa lebih memahami dan mengerti tentang konsep abstrak matematika yang diinformasikan kepadanya. Siswa yang diajar lebih mudah memahami materi pelajaran jika ditunjang dengan media belajar atau alat peraga.

Pecahan yang dipelajari siswa ketika di sekolah dasar, sebenarnya merupakan bagian dari bilangan irasional yang dapat ditulis dalam bentuk $\frac{a}{b}$ dimana a dan b adalah bilangan bulat, dan $\mathrm{b}$ tidak sama dengan nol. Secara simbolik pecahan dapat dinyatakan sebagai salah satu dari pecahan biasa, pecahan campuran, desimal, dan persen. Menurut Kennedy (1994:425), makna dari pecahan dapat diartikan sebagai bagian yang berukuran sama dari yang utuh atau keseluruhan. Selanjutnya Kennedy mengatakan bahwa pecahan sebagai bagian dari kelompok-kelompok yang beranggotakan sama banyak, atau juga menyatakan pembagian.

Heruman (2008 : 43) berpendapat bahwa pecahan adalah bilangan yang menyatakan bagian dari sesuatu yang utuh. Marsigit (2009 : 34) mengungkapkan bahwa bilangan yang dinyatakan dalam bentuk $\frac{a}{b}$, dengan a dan $\mathrm{b}$ adalah bilangan bulat, $\mathrm{b} \neq 0$, dan $\mathrm{b}$ bukan factor dari $\mathrm{a}$. Hal ini seperti diuangkapkan oleh Hatfield, dkk (1993 : 326) "since b represent the basic unit of wholeness, $b$ cannot equal 0 because it would mean that there was no complete unit with which to compare other portions".

Dari paparan di atas dapat disimpulkan bahwa pecahan adalah bilangan yang menyatakan bagian dari keseluruhan bagian yang utuh yang dinyatakan dalam bentuk $\frac{a}{b}$, dengan syarat a dan $b$ adalah bilangan bulat, $\mathrm{b} \neq 0$, dan a bukan kelipatan dari $\mathrm{b}$. Dari beberapa pengertian tersebut, muncullah gagasan untuk penciptaan alat pembelajaran pecahan yaitu puzzle pecahan. Bahwa pada intinya pecahan merupakan bagian yang berukuran sama dari suatu yang utuh (bulat). Kemudian satu bagian yang utuh tersebut dipotong-potong menjadi bagian yang lebih kecil yang disebut pecahan. Besarnya potongan tersebut tergantung dari berapa banyak sebuah potongan yang dilakukan.

Puzzle pecahan yang dirancang ini merupakan sebuah media pembelajaran. Puzzle pecahan merupakan benda-benda media belajar yang dimanipulasi untuk membantu siswa dalam memahami konsep-konsep yang abstrak dari nilai suatu pecahan. 

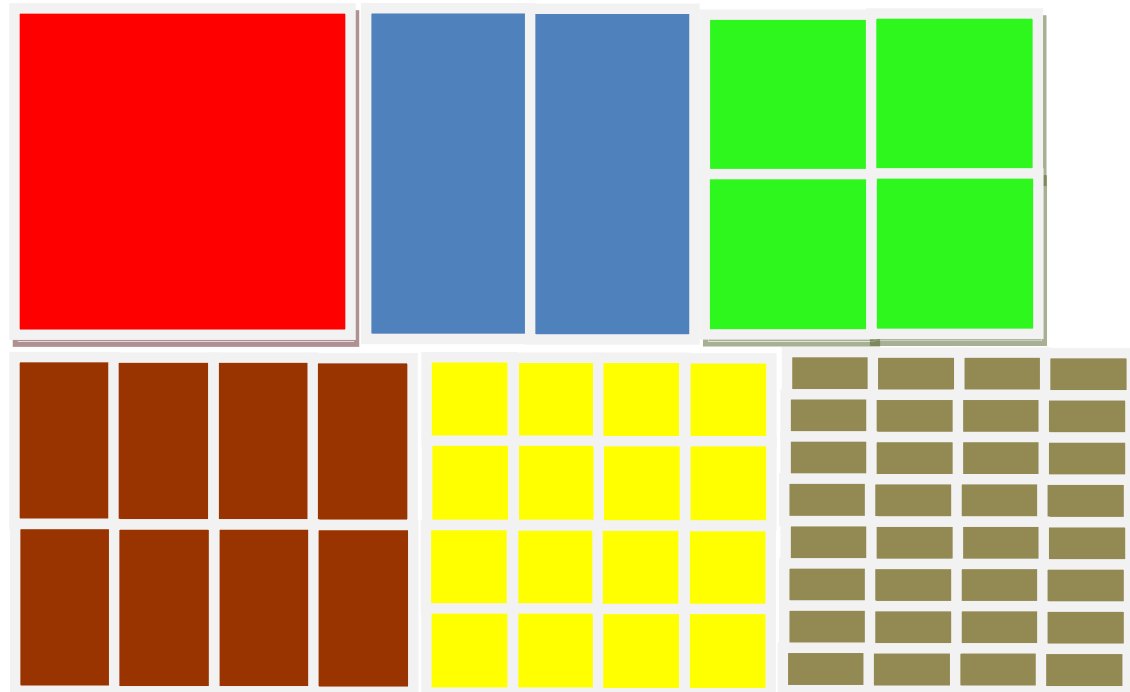

Gambar-gambar di atas merupakan benda-benda yang terbuat dari triplek palastik dan selanjutnya dapat kita manipulasi untuk mewakli nilai suatu pecahan, yang selanjutnya bisa kita sebut sebagai puzzle pecahan. Misal di awali dari puzzle warna merah yang bernilai 1 , dan dilanjutkan pengenalan puzzle warna biru yang masing-masing bagian bernilai $\frac{1}{2}$, selanjutnya puzzle warna hijau yang masing-masing bagian bernilai $\frac{1}{4}$, kemudian puzzle warna coklat yang masing-masing bagian bernilai $\frac{1}{8}$, berikutnya puzzle warna kuning masing-masing bernilai $\frac{1}{16}$, dan terakhir puzzle warna abu-abu yang masing-masing bagian bernilai $\frac{1}{32}$. Semua puzzle ini selanjutnya akan kita gunakan untuk memahami berbagai kompetensi dasar yang harus di kuasai siswa pada kurikulum sekolah dasar.

Misalkan diberikan contoh soal sebagai berikut $: \frac{1}{2}+\frac{1}{4}$

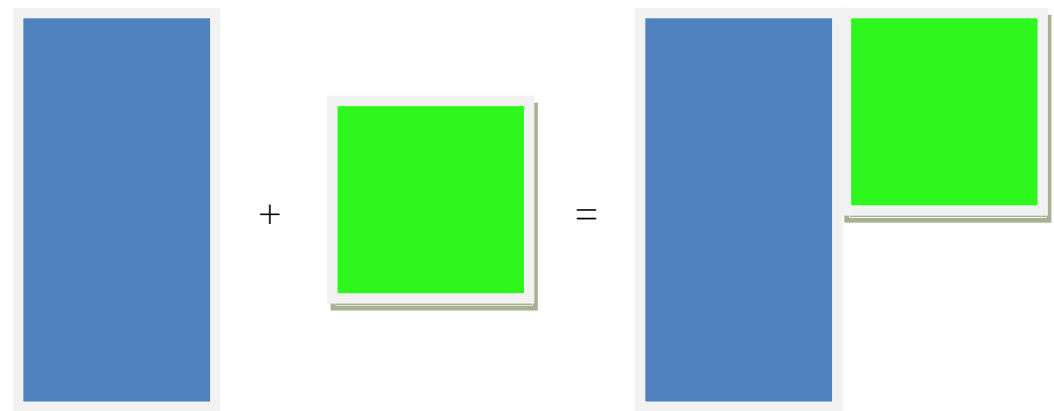

Gambar di atas merupakan ilustrasi dari pecahan yang bernilai $\frac{1}{2}$ (puzzle pecahan warna biru) dan pecahan bernilai $\frac{1}{4}$ (puzzle warna hijau). Menyelesaikan masalah penjumlahan pecahan menggunakan puzzle pecahan, pertama disamakan warna puzzle dengan merubah warna puzzle yang besar mengikuti warna puzzle yang kecil. Setelah sama puzzle disusun ulang mengikuti bentuk puzzle warna merah (bentuk standar). Hasilnya disajikan pada gambar berikut ini. 


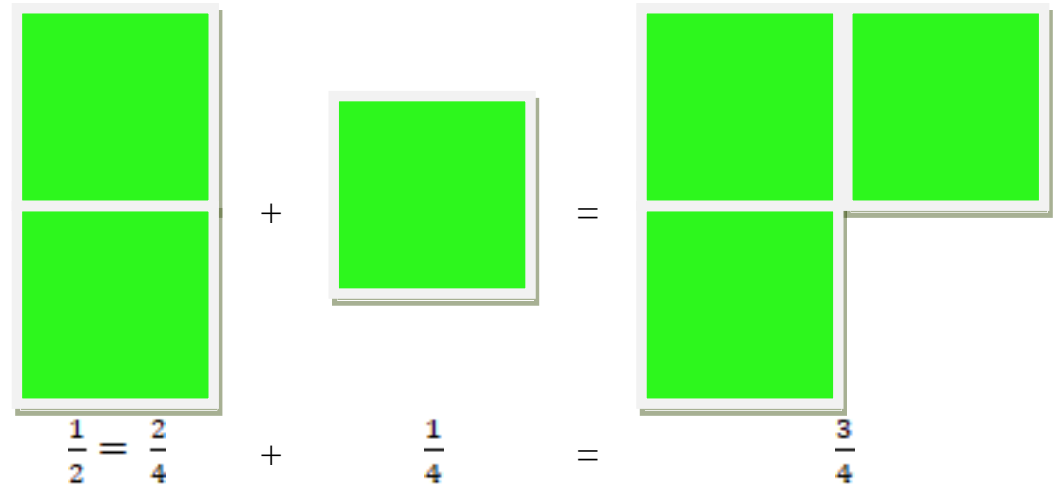

Gambar ilustrasi diatas menggambarkan secara jelas bahwa $\frac{1}{2}+\frac{1}{4}$ hasilnya adalah $\frac{3}{4}$. Akhirnya dengan bantuan puzzle pecahan permasalahan penjumlahan pecahan biasa berpenyebut tidak sama dengan mudah dapat diselesaikan.

Kata 'realistik' merujuk pada pendekatan pembelajaran dalam pendidikan matematika yang telah dikembangkan Belanda selama kurang lebih 33 tahun. Kata tersebut diambil dari klasifikasi yang dikemukakan Zulkardi 2002 yang membedakan pendekatan pembelajaran dalam pendidikan matematika yaitu mechanistic, empiristic, strukturalistic, dan realistic. Pendekatan matematika realistik mengacu pada pendapat Freudenthal (2002) yang mengatakan bahwa matematika adalah aktivitas manusia dan banyak berhubungan dengan realitas.

Hadi (2005 : 19) menjelaskan bahwa dalam matematika realistik dunia nyata digunakan sebagai titik awal untuk pengembangan ide dan konsep matematika. Tarigan (2006:3) menambahkan bahwa pembelajaran matematika realistic menekankan akan pentingnya konteks nyata yang dikenal siswa dan proses konstruksi pengetahuan matematika oleh siswa sendiri. Aisyah (2007 : 7) mengemukakan bahwa pendekatan matematika realistic merupakan suatu pendekatan belajar matematika yang dikembangkan untuk mendekatkan matematika kepada siswa. Ahmad Faudzan (2002) mengemukakan bahwa pendekatan matematika realistik pada dasarnya adalah pemanfaatan realitas dan lingkungan yang dipahami oleh peserta didik untuk memperlancar proses pembelajaran matematika sehingga dapat mencapai tujuan pendidikan matematika secara lebih baik daripada masa lalu.

Berdasarkan beberapa pengertian di atas dapat disimpulkan bahwa pendekatan matematika realistik pada dasarnya merupakan pendekatan pembelajaran matematika yang memanfaatkan realitas dan lingkungan yang dipahami siswa untuk memperlancar proses pembelajaran matematika sehingga dapat mencapai pendidikan matematika secara lebih baik daripada masa yang lalu. Seperti halnya pandangan baru tentang proses belajar mengajar, dalam pendekatan matematika realistik juga diperlukan upaya mengaktifkan siswa. Upaya tersebut dapat diwujudkan dengan cara mengoptimalkan keikutsertaan unsur-unsur proses belajar mengajar dan mengoptimalkan keikutsertaan seluruh sense peserta didik. Salah satu kemungkinannya adalah dengan memberikan kesempatan kepada siswa untuk dapat menemukan atau menkonstruksi sendiri pengetahuan yang akan dikuasainya.

Pendekatan matematika realistik memberikan kemudahan bagi guru matematika dalam mengembangkan konsep-konsep dan gagasan-gagasan matematika bermula dari dunia nyata. Dunia nyata tidak berarti konkret secara fisik dan kasat mata, namun juga termasuk yang dapat dibayangkan oleh pikiran anak. Jadi dengan demikian pendekatan matematika realistik menggunakan situasi dunia nyata atau suatu konteks nyata sebagai titik tolak belajar matematika.

Terkadang para peserta didik untuk memahami bilangan bulat secara abstrak saja sudah mengalami kesulitan tersendiri. Apalagi jika harus memahami bilangan pecahan secara abstrak, akan menambah kesulitan tingkat tinggi. Beberapa tenaga pendidik (guru) diberbagai satuan pendidikan telah banyak melakukan penelitian untuk mengatasi hal ini. Para guru berusaha untuk menciptakan berbagai media belajar agar pecahan ini dapat dipahami siswa secara konkrit.

Beberapa media pembelajaran telah berhasil diciptakan oleh para guru maupun para penulis buku matematika. Para penulis buku matematika banyak yang memaparkan pengajaran pecahan melalui gambar bangun datar yang diarsir atau melalui praktik pemotongan buah-buahan. Ada pula 
yang menawarkan pembelajaran pecahan melalui tabel pecahan. Beberapa orang guru juga berhasil menciptakan sebuah alat pembelajaran yang kemudian dituangkan penelitiannya tersebut dalam sebuah Penelitian Tindakan Kelas (PTK) atau skripsi, diantaranya : Penggunaan Media Kertas Lipat Guna Meningkatkan Hasil Belajar Perkalian Pecahan pada Siswa Kelas V SDK Ru'a Tahun Pelajaran 2012/2013 Oleh Adrianus San Mahasiswa PGSD STKIP ST. PAULUS-RUTENG, Penggunaan Media Pembelajaran Kartu Domino pada Materi Bilangan Pecahan Menggunakan Model Pembelajaran Realistic Mathematic Education Oleh Siti Khomsatun Mahasiswa FKIP Pendidikan Matematika Universitas Muhammadiyah Purwokerto

Berdasarkan landasan teori yang ada maka hipotesis pada penelitian tindakan kelas ini adalah pembelajaran materi menjumlahkan dua pecahan biasa berpenyebut tidak sama menggunakan media belajar puzzle pecahan dapat meningkatkan nilai hasil belajar siswa khususnya di kelas IV Ibnu Rusyd SD al muslim Bekasi.

\section{METODE PENELITIAN}

Metode penelitian yang akan digunakan untuk menjawab rumusan masalah dan hipotesis penelitian adalah dengan penelitian tindakan kelas yang dilakukan secara berulang, dengan beberapa siklus.

Teknik pengumpulan data yang digunakan merujuk pada tujuan yang ingin dicapai dalam penelitian ini, maka teknik pengumpulan data yang digunakan adalah sebagai berikut :Tes tertulis, setiap siklus ini melalui serangkaian tes tertulis (LKS) yang dijadikan sebagai alat evaluasi untuk mengukur daya serap kemampuan siswa dalam memahami materi mencari hasil operasi penjumlahan dua pecahan biasa berpenyebut tidak sama. Pada siklus pertama dan kedua masing-masing siswa diberikan 10 soal tertulis. Pengamatan, sumber pengamatan selama berlangsungnya kegiatan pembelajaran merupakan suatu bagian penelitian secara individu.

Teknik analisis data merupakan bagian penting dalam sebuah penelitian. Hal ini perlu dilakukan karena analisis data yang diperoleh pada suatu penelitian dapat memberi arti penting terhadap hasil penelitian tersebut. Teknik analisis data digunakan untuk menguji hipotesis pada setiap siklus. Untuk menguji hipotesis, digunakan analisis statistik deskriptif melalui perbandingan rata-rata nilai hasil belajar siswa sebelum (menggunakan cara konvensional, tanpa media) dan sesudah mengggunakan media belajar puzzle pecahan hasil penjumlahan dua pecahan biasa berpenyebut tidak sama .

Secara umum prosedur pelaksanaan penelitian tindakan kelas ini meliputi empat tahap, yaitu : (1) perencanaan, (2) pelaksanaan tindakan, (3) observasi atau pengamatan, dan (4) refleksi. Penelitian tindakan kelas ini dilakukan dalam tiga siklus untuk mencapai hasil yang diinginkan dan mengatasi persoalan yang ada. Sebelumnya dilakukan pra siklus yaitu penyampaian materi pengurangan dua pecahan biasa berpenyebut tidak sama tanpa menggunakan media belajar. Kemudian siklus satu akan dilanjutkan ke siklus berikutnya jika belum mencapai kriteria keberhasilan atau ketuntasan belajar yang telah ditetapkan oleh guru. Pada penelitian ini tahapan pada siklus kedua dirasakan sudah cukup mencapai kriteria ketuntasan belajar minimum.

\section{HASIL PENELITIAN DAN PEMBAHASAN}

Untuk melihat efektifitas hasil penggunaan media puzzle pecahan ini, saya telah mengujicobakan puzzle pecahan ini pada kelas 4 Ibnu Rusyd SD al muslim Tambun Bekasi pada materi penjumlahan pecahan biasa dengan penyebut tidak sama. Penelitian dilakukan selama 3 kali percobaan. Percobaan pertama para siswa diberikan penjelasan tentang materi penjumlahan pecahan biasa dengan penyebut tidak sama secara konvensional. Setelah penjelasan dirasa cukup untuk dipahami oleh para siswa maka guru pun memberikan LKS 10 soal latihan untuk dijawab para siswa sebagai tolak ukur pemahaman materi penjumlahan pecahan dengan penyebut tidak sama. Nilai hasil belajar siswa dicatat sebagai nilai pertama percobaan.

Kemudian percobaan kedua para siswa diberikan penjelasan tentang penggunaan media puzzle pecahan pada materi penjumlahan pecahan dengan penyebut tidak sama. Untuk menambah keseruan permainan dengan puzzle pecahan ini para siswa dibentuk kelompok yang terdiri dari 3 orang. Setiap siswa diberi nomor dada sebagai nomor urut untuk menjawab soal, siswa yang menjawab dengan cepat dan tepat itulah pemenangnya. Selanjutnya guru menyiapkan LKS untuk 
melihat daya serap siswa secara individu tentang penggunaan puzzle pecahan pada materi penjumlahan pecahan dengan penyebut tidak sama. Nilai hasil belajar siswa dicatat sebagai nilai percobaan kedua. Terakhir percobaan ketiga diberikan keesokan harinya, diberikan dibagian apersepsi untuk masuk ke materi pengurangan pecahan dengan penyebut tidak sama. Hasilnya disajikan dalam tabel berikut ini.

Tabel 1.

Rekapitulasi Nilai Hasil Belajar Siswa

\begin{tabular}{llll}
\hline & Perc 1 & Perc 2 & Perc 3 \\
\hline KKM & 75 & 75 & 75 \\
\hline Jumlah Siswa & 28 & 28 & 28 \\
\hline Jumlah Yang Tuntas & 11 & 18 & 28 \\
\hline Jumlah Yang Tidak Tuntas & 17 & 10 & 0 \\
\hline Rata-rata & 65,20 & 75,40 & 80,40 \\
\hline Nilai Tertinggi & 85,00 & 90,00 & 90,00 \\
\hline Nilai Terendah & 40,00 & 65,00 & 75,00 \\
\hline Simpangan Baku & 1,48 & 0,58 & 0,47 \\
\hline Di atas Rata-rata & 7 & 13 & 7 \\
\hline Di bawah Rata-rata & 21 & 15 & 21 \\
\hline
\end{tabular}
bawah ini.

Untuk lebih jelasnya perkembangan nilai hasil belajar siswa disajikan pada diagram garis di

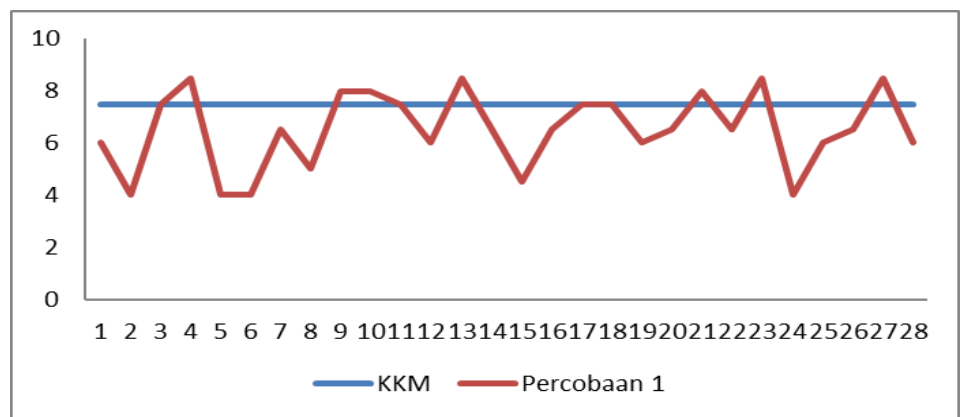

Gambar 1.

Pencapaian Nilai Hasil Belajar pada Percobaan 1

Gambar 1 di atas merupakan grafik pencapaian nilai hasil belajar siswa pada awal pengamatan. Pada awal pengamatan ini dilakukan pembelajaran tanpa menggunakan media puzzle pecahan. Jika dilihat gambar tersebut nampak jelas pencapaian nilai siswa yang berada di atas KKM hanya 17 siswa atau 60,71 \% siswa nilai hasil belajarnya masih di bawah KKM. Kondisi seperti sangat memprihatinkan. Guru diharapkan dapat memperbaiki kondisi ini.

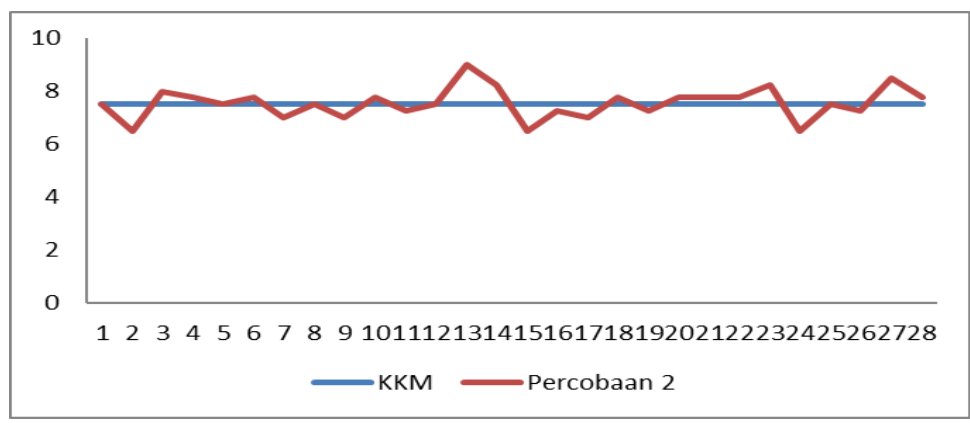

Gambar 2.

Pencapaian Nilai Hasil Belajar pada Percobaan 2 
Pada percobaan kedua, pembelajaran dilaksanakan dengan bantuan puzzle pecahan. Pada grafik gambar 2 di atas nampak ada perubahan nilai hasil belajar siswa ke arah yang lebih baik, terbukti jumlah siswa yang mencapai nilai hasil belajar berkurang menjadi 10 anak atau hanya sebesar $35,71 \%$ saja yang berada di bawah KKM.

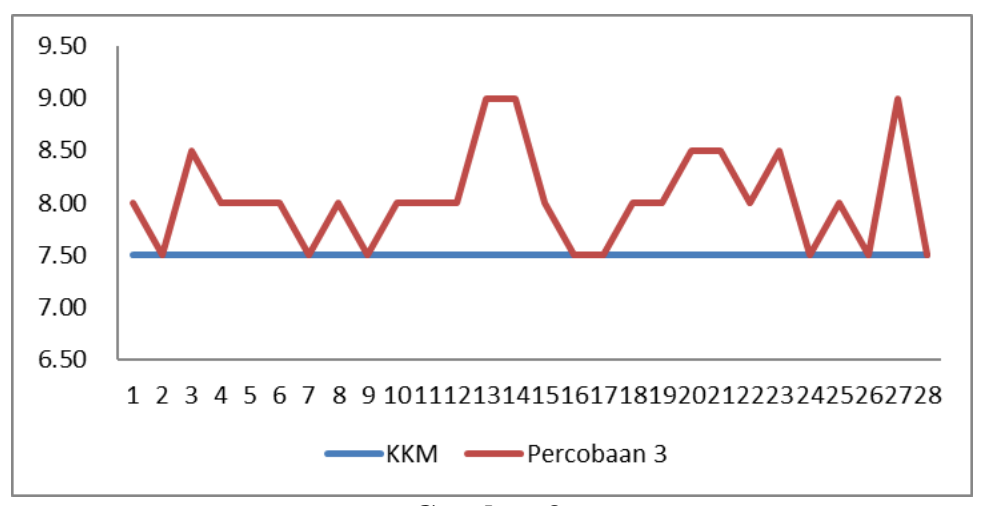

Gambar 3.

Pencapaian Nilai Hasil Belajar pada Percobaan 3

Pada gambar 3, merupakan siklus 2 menggunakan media puzzle pecahan. Pada grafik di atas terlihat jelas bahwa seluruh nilai hasil belajar siswa telah berhasil berada di atas KKM. Selanjutnya peningkatan nilai hasil belajar siswa dari setiap percobaan dapat kita hitung besarnya. Berdasarkan perhitungan peningkatan nilai rata-rata hasil belajar pada percobaan di atas dapat disimpulkan bahwa ada peningkatan hasil belajar sebesar $15,64 \%$ pada percobaan 2 dan peningkatan nilai rata-rata hasil belajar sebesar $23,31 \%$ pada percobaan 3 sesudah menggunakan puzzle pecahan pada materi penjumlahan pecahan biasa dengan penyebut tidak sama. Hal ini dapat diartikan bahwa penggunaan puzzle pecahan dapat meningkatkan hasil belajar siswa. Hal ini sejalan dengan Vita Marta Sari (2014 : 216) dalam sebuah penelitiannya yang berjudul "Efektifitas Penggunaan Media Puzzle dalam Meningkatkan Kemampuan Mengenal Konsep Bilangan Pecahan Sederhana Bagi Anak Kesulitan Belajar" menemukan bahwa media puzzle pecahan efektif dalam meningkatkan kemampuan untuk mengetahui konsep bilangan pecahan sederhana bagi anak kesulitan belajar dan menyarankan penggunaan media puzzle ini sebagai alternative mengajarkan pecahan pada pelajaran matematika. Hal ini seiring dengan pendapat Hana Rosita $(2016$ : 1) dalam penelitiannya yang berjudul "Pengembangan Media Fraction Puzzle pada Pembelajaran Matematika Materi Pecahan Senilai untuk Siswa Kelas IV Sekolah Dasar" bahwa puzzle pecahan dapat meningkatkan nilai hasil belajar siswa.

\section{SIMPULAN DAN SARAN}

Berdasarkan hasil pembahasan yang telah dilakukan, maka dapat disimpulkan bahwa :

1. Penggunaan puzzle pecahan dapat meningkatkan nilai hasil belajar siswa dalam memahami materi pecahan. Hal ini terbukti dari ketiga percobaan di atas. Percobaan pertama, pembelajaran materi penjumlahan pecahan tanpa menggunakan puzzle nilai siswa sekitar 60\% di bawah KKM. Kemudian pada percobaan kedua dengan menggunakan puzzle pecahan jumlah siswa yang berada di bawah KKM turun menjadi 35\% artinya ada peningkatan hasil belajar sebanyak $15 \%$. Kemudian dilakukan percobaan yang ketiga, hasilnya cukup menggembirakan tidak ada seorang pun siswa yang berada di bawah KKM atau telah terjadi peningkatan hasil belajar sebesar $23 \%$.

2. Penggunaaan puzzle pecahan akan sangat membantu guru dalam menjelaskan apa itu pecahan. Puzzle pecahan juga akan sangat membantu siswa dalam memahami berbagai kompetensi dasar tentang pecahan, seperti mencari pecahan senilai, membandingkan pecahan, mengurutkan pecahan, serta pada operasi hitung pecahan. Puzzle pecahan sangat membantu guru dan siswa dalam memahami pecahan dengan pendekatan realistik.

3. Aktivitas pembelajaran pecahan di kelas menggunakan puzzle pecahan akan menarik bagi guru dan siswa karena terjadi komunikasi dua arah bukan teacher centris. Peranan puzzle pecahan sebagai media atau alat peraga dalam pembelajaran pecahan membuat suasana belajar di kelas menjadi kondusif untuk siswa dapat berpikir kritis, kreatif, dan eksploratif sehingga anak dapat 
berpikir bebas dan berpendapat sesuai potensinya. Apalagi jika dilengkapi dengan strategi mengajar guru yang memberi beberapa soal tantangan dengan pendekatan problem solving dan bekerjasama dalam kelompok, akan membantu membangun pengetahuan siswa untuk berpikir efektif dan strategis dalam menyelesaikan permasalahan.

Puzzle pecahan adalah hanya sebuah media belajar untuk membantu siswa dalam memahami pecahan, masih diperlukan kreativitas guru dalam proses pembelajaran di kelas. Seperti bagaimana menyampaikan materi dan strategi pembelajaran yang tidak boleh monoton, harus dikemas agar menarik bagi siswa. Karena jika pembelajaran pecahan menggunakan puzzle pecahan diberikan dengan strategi yang konvensional akan terjadi pembelajaran yang menjemukan bagi siswa, hal inilah yang harus dihindari oleh para guru.

\section{UCAPAN TERIMA KASIH}

Syukur Alhamdulillah senantiasa penulis panjatkan kehadirat Allah SWT yang memiliki keistimewaan dan pemberian segala nikmatNya. Sholawat serta salam senantiasa tercurahkan kepada Nabi Muhammad SAW, keluarga dan para sahabatnya.

Pada kesempatan ini penulis mengucapkan terima kasih kepada kepala SD al muslim Bekasi yakni Ibu Endah Setiaharti, M.Pd atas kesempatannya untuk melakukan penelitian di sekolah, serta dukungan rekan-rekan guru atas kerjasama dan masukan untuk penyempurnaan penelitian ini. Kepada keluarga tercinta, terutama ummi tercinta atas doa di setiap sujudnya. Akhirnya, penulis berharap semoga penelitian ini dapat bermanfaat untuk kita semua.

\section{DAFTAR PUSTAKA}

Arsyad, Azhar. 2011. Media Pembelajaran. Jakarta : Rajawali Pers

Asyar, Rayandra. 2012. Kreatif Mengembangkan Media Pembelajaran. Jakarta : Gaung Persada Press.

Depdiknas. 2003. Undang-undang No 20 Tahun 2003 tentang SISDIKNAS, Jakarta.

Depdinas. 2003. Kegiatan Belajar Mengajar KBK, Jakarta : Pusat Kurikulum Balitbang.

Faudzan, Ahmad. 2002. Applying Realistic Mathematics Education (RME) in Teaching Geometry in Indonesian Primary Schools. Disertasi. Den Haag : University of Twente.

Freudenthal, Hans. 2002. Didactical Phenomonology of Mathematical Structures. Kluwer Academic Publisher : New York.

Halimah, N. (2017). Perbedaan Pengaruh Model Student Teams Achievement Division (Stad) dan Numbered Heads Together (NHT) Terhadap Hasil Belajar Matematika Siswa Kelas V SD. Scholaria: Jurnal Pendidikan Dan Kebudayaan, 7(3), 267-275. https://doi.org/https://doi.org/10.24246/j.scholaria.2017.v7.i3.p267-275

Juniati, E. (2017). Peningkatkan Hasil Belajar Matematika Melalui Metode Drill dan Diskusi Kelompok pada Siswa Kelas VI SD. Scholaria: Jurnal Pendidikan Dan Kebudayaan, 7(3), 283-291. https://doi.org/https://doi.org/10.24246/j.scholaria.2017.v7.i3.p283-291

Kennedy, Leonard. 1994. Guiding Children's Learning of Mathematics. California : Wadsworth Publishing Company.

Andriani, M., \& -, W. (2016). Pengembangan Media Pembelajaran Power Point Interaktif Melalui Pendekatan Saintifik untuk Pembelajaran Tematik Integratif Siswa Kelas 2 SDN Bergas Kidul 03 Kabupaten Semarang. Scholaria: Jurnal Pendidikan Dan Kebudayaan, 6(1), 143-157. https://doi.org/https://doi.org/10.24246/j.scholaria.2016.v6.i1.p143-157

Putri, Ratu, I.I. 2009. Efek Potensial Pelatihan PMRI terhadap Guru-Guru Matematika di Palembang. Jurnal Pendidikan Matematika, Vol. 3 (2) Hal. 85 - 91. Palembang : Universitas Sriwijaya. 
Pendekatan Matematika Realistik dengan Bantuan Puzzle Pecahan untuk Siswa Sekolah Dasar (Achmad Firdaus)

Raharjo, Erica. 2017. Pengaruh Penggunaan Media Pembelajaran Puzzle Pecahan Campuran terhadap Hasil Belajar Siswa pada Mata Pelajaran Matematika di Kelas IV SD Negeri Banyuanyar 3 Surakarta Tahun Pelajaran 2016/2017. Tesis. FKIP Universitas Slamet Riyadi. Surakarta.

Rahmadani, N., \& Anugraheni, I. (2017). Peningkatan Aktivitas Belajar Matematika Melalui Pendekatan Problem Based Learning bagi Siswa Kelas 4 SD. Scholaria: Jurnal Pendidikan Dan Kebudayaan, 7(3), 241-250. https://doi.org/https://doi.org/10.24246/j.scholaria.2017.v7.i3.p241-250

Rosita, Hana. 2016. Pengembangan Media Fraction Puzzle pada Pembelajaran Matematika Materi Pecahan Senilai untuk Siswa Kelas IV Sekolah Dasar. Skripsi. Program Studi PGSD, Fakultas Ilmu Pendidikan, Universitas Negeri Malang.

Sari, Vita Marta. 2014. Efektifitas Penggunaan Media Puzzle dalam Meningkatkan Kemampuan Mengenal Konsep Bilangan Pecahan Sederhana Bagi Anak Kesulitan Belajar. Jurnal Ilmiah Pendidikan Khusus, Vol. 3(1) Hal 216-226.

Ulya. 2010. Desain Bahan Ajar Penjumlahan Pecahan Berbasis Pendidikan Matematika Realistik untuk Siswa Kelas IV Sekolah Dasar Negeri 23 Indralaya. Jurnal Pendidikan Matematika, Vol. 4(2) Hal. 86 - 96. Palembang : PPS UNSRI.

Yayasan Pembinaan Masjid Salam ITB. 2003. Program Pembinaan Guru Matematika dan Sains Berbasis Kompetensi, kreativitas dan Spiritual Tingkat SD \& SMP, Bandung : Direktorat Pembinaan Pendidikan dan Pelatihan Departemen Pendidikan Nasional.

Zulkardi. 2002. Developing a Learning Environment on Realistic Mathematics Education for Indonesian Stident Teachers. Disertasi. Den Haag : Universty of Twente. 